Nalar: Jurnal Peradaban dan Pemikiran Islam

Volume 4 Nomor 1, Juni 2020

http://e-journal.iain-palangkaraya.ac.id/index.php/nalar

E-ISSN: 2598-8999, P-ISSN: 2597-9930

\title{
Komunikasi dan Akulturasi: Studi Fenomenologi pada Masyarakat Lokal dan Muslim di Perbatasan Indonesia- Malaysia
}

\author{
Bob Andrian \\ Institut Agama Islam Negeri Pontianak, Indonesia \\ bob_andrian@iainptk.ac.id
}

\begin{tabular}{|c|c|}
\hline Keywords : & Abstract \\
\hline $\begin{array}{l}\text { Acculturation, } \\
\text { Communication, } \\
\text { Border Society }\end{array}$ & $\begin{array}{l}\text { This study attempted to analyze the process of communication and socio-cultural } \\
\text { acculturation, especially local society with Muslims at the border. This research was } \\
\text { qualitative using a naturalistic paradigm, with a phenomenological approach. Data were } \\
\text { obtained through three ways, namely observation, interviews and documentation. The research } \\
\text { method was a case study. The analysis revealed that, first, acculturation in border society } \\
\text { occured because there were five aspects affecting it such as increasing population, increasing } \\
\text { levels of education, easy and free access to economy, attractions and socio-cultural heterogeneity } \\
\text { at the border. The existence of these factors contributed greatly to the reconstruction of the } \\
\text { social order of border society. The process of dialectics and communication between cultures of } \\
\text { local society and Muslims was bound to make the acculturation process between the two or } \\
\text { vice versa. Based on the field findings, there were at least two forms of acculturation process, } \\
\text { namely culutural cover and overt cultural. Second, the form of acculturation bad two major } \\
\text { influences on the local society in particular and the migrant society in general both negative } \\
\text { and positive influences. Negative influences included the declining local culture, which began to } \\
\text { diminish and traditional lifestyles beginning to change more modern. Meanwhile, positive } \\
\text { influences included more practical methods of farming to support local society life, ways of } \\
\text { thinking that were more advanced and developing, and more modern lifestyles. As for the } \\
\text { acculturation process, it emerged several cultures. Among of them were to create new cultures, } \\
\text { such as farming culture, lifestyle, and knowledge. There were also those who maintained the } \\
\text { existence of each cultural substance such as language, values and innate norms inherent in the } \\
\text { element of origin of culture. Also, it eliminated the culture existed between the two cultures, } \\
\text { both the local people culture and the newcomers culture including the way of life from the } \\
\text { traditional farming patterns to being more modern. }\end{array}$ \\
\hline $\begin{array}{l}\text { Kata Kunci : } \\
\text { Akulturasi, } \\
\text { Komunikasi, } \\
\text { Masyarakat } \\
\text { Perbatasan. }\end{array}$ & $\begin{array}{l}\text { Abstrak } \\
\text { Penelitian ini bertujuan untuk menganalisis proses komunikasi dan akulturasi sosial } \\
\text { budaya, khususnya masyarakat lokal dengan muslim di perbatasan. Penelitian ini adalah } \\
\text { kualitataif menggunakan paradigma naturalistik, dengan pendekatan fenomenologi. Data } \\
\text { diperoleh melalui tiga cara, yaitu observasi, wawancara dan dokumentasi. Adapun metode } \\
\text { yang digunakan untuk menganalisis data ialah studi kasus. Berdasarkan hasil analisis } \\
\text { data, diperoleh dua simpulan. Pertama, akulturasi yang terjadi pada masyarakat } \\
\text { perbatasan terjadi karena ada lima aspek yang mempengarubinya, diantaranya aspek } \\
\text { peningkatan jumlah penduduk, peningkatan tingkat pendidikan, mudah dan bebasnya } \\
\text { akses perekonomian, objek wisata dan hetrogenitasnya sosial budaya di perbatasan. Adanya } \\
\text { faktor tersebut, memberikan kontribusi besar terhadap rekonstruksi tatanan sosial } \\
\text { masyarakat perbatasan. Adanya proses dialektika dan komunikasi antar budaya } \\
\text { masyarakat lokal dengan muslim diperbatasan menjadikan terjadinya proses akulturasi } \\
\text { antara keduanya atau sebaliknya. Berdasarkan hasil temuan lapangan paling tidak ada } \\
\text { dua bentuk proses akulturasi, yaitu cover culutural dan overt cultural. Kedua, bentuk }\end{array}$ \\
\hline
\end{tabular}




\begin{tabular}{l} 
akulturasi ini mengakibatkan dua pengarub besar bagi masyarakat setempat khususnya \\
dan masyarakat pendatang umumnya baik negatif maupun positif. Pengaruh yang negatif \\
meliputi mulai lunturnya budaya lokal yang mulai berkurang dan pola bidup tradisional \\
yang mulai berganti lebih modern. Sedangkan pengaruh yang sifatnya positif meliputi, cara \\
bercocok tatanam yang lebih praktis untuk menunjang kelangusngan bidup masyarakat \\
setempat, cara berfikir yang lebih maju dan berkembang, dan gaya bidup yang lebih modern. \\
Adapun berdasarkan proses akulturasi yang terjadi, melabirkan beberapa budaya, di \\
antaranya, melabirkan budaya baru, seperti halnya budaya bercocok tanam, gaya bidup, \\
dan llmu pengetabuan. Ada juga yang tetap menjaga eksistensi masing-masing substansi \\
budaya seperti, bahasa, nilai dan norma bawaan yang melekat pada unsur budaya asalnya. \\
Serta, menghilangkan budaya yang ada antara kedua budaya baik itu budaya masyarakat \\
lokal maupun budaya masyarakat pendatang diantaranya cara bidup dari pola bercocok \\
tanam yang tradisional ditinggalkan menjadi lebih modern. \\
\hline Received:27-4-2020 Accepted:19-6-2020
\end{tabular}

\section{PENDAHULUAN}

Indonesia sangat kaya akan tradisi dan kebudayan nenek moyang yang mengakar di tatanan sosial masyarakat. Jauh sebelum Indonesia diakui menjadi resmi sebuah negara, kebudayaan masyarakat bangsa ini telah dikenal dan diketahui oleh negara-negara luar. Fakta sejarah menjelaskan kepada dunia bahwa bangsa ini sangat terkenal dengan beragam aliran kepercayaan yang yakini. Sebagaimana disebutkan oleh, Lubis (1993) bahwa kebudayaan leluhur masyarakat pribumi sangat kental dengan beragam kepercayaan lokal, seperti adanya animisme, dinamisme, dan sebagainya yang diyakini oleh nenek moyang bangsa Indonesia. Tidak hanya kepercayaan lokal, kebudayaan masyarakat juga dipengaruhi oleh beberapa "Agama impor" datang ke Indonesia, seperti Hindu, Budha, Islam, Kristen, Konghuchu (Maarif 2017). Dalam pandangan Mualimin (2020; 2018), agama dan kepercayaan seringkali saling memberikan pengaruh kepada unsur kebudayaan di masyarakat. Proses transmisi nilai inilah kemudian menjadi tradisi dan ciri khas masyarakat di tengah-tengah heterogenisitas suku agama dan ras Indonesia. Akhirnya dialetika sosial dan budaya masyarakatnya menjadi tidak terpisahkan dalam proses komunikasi Sosial Budaya antara masyarakat satu dengan yang masyarakat yang lainnya.

Berbagai perubahan kebijakan yang berlaku di Indonesia juga memberikan kontribusi bagi penyebaran atau pemerataan kebudayaan yang ada di masayarakat. Sebagai contoh, ketika kebijakan pemerintah pada masa orde baru pasca kemerdekaan melakukan Trilogi pembangungan, yaitu stabilitas politik negara, pertumbuhan dan stabilisasi ekonomi, dan pemerataan pembangunan (Khairani 2015). Pada aspek program pemerataan pembangunan, salah satunya ialah pemerataan penduduk, dimana banyak masyarakat pulau Jawa yang di transmigrasikan ke beberapa pulau yang memiliki potensi, seperti pulau Sumatera, Kalimantan, Sulawesi bahkan sampai pada Papua (Hidayat 2018).

Tujuan pemerataan pembangunan tersebut, diharapkan memberikan sumbangsih pada pertumbuhan ekonomi di beberapa bidang. Karena ekonomi yang meningkat juga akan banyak membutuhkan tenaga pekerja dan karyawan-karyawan di perusahan. Sehingga, persebaran tenaga kerja berbanding lurus dengan banyaknya penyebaran penduduk di beberapa daerah seluruh Indonesia, tanpa terkecuali di Kalimantan Barat. Termasuk di antaranya beberapa daerah perbatasan Kalimantan Barat, karena banyak perusahaan besar industri perkebunan ini berkembangnya di perbatasan, termasuk Sambas di antaranya. Contoh lainnya ialah kebijakan pemerintah yang menjadi alasan adanya komunikasi sosial budaya masyarakat adalah dibukanya jalur perbatasan yang menghubungan suatu negara dengan negara tetangga yang secara letak georafisnya yang berada di batas negara. Maka, secara eksistensinya suatu daerah yang bersinggungan langsung dengan daerah luar negeri 
penduduknya akan berkomunikasi secara langsung dengan masyarakat luar negeri. Penyebaran penduduk di berbagai wilayah-wilayah Indonesia dan letak geografis inilah kemudian menyebabkan adanya dialektika dan saling komunikasi antara masyarakat satu dengan lainnya. Melalui komunikasi ini kemudian terjadilah beragam proses interaksi yang berlangsung, diantaranya adalah interaksi antar budaya, antar suku, antar agama dan antar ras yang terjadi di daerah perbatasan.

Data terakhir dari 187 kecamatan ada 42 wilayah kabupaten atau kota di 13 provinsi merupakan daerah terluar dan terdepan di Indonesia, 10 wilayah di antaranya merupakan daerah yang menjadi prioritas kegiatan strategis nasional (Sekretariat Kabinet Republik Indonesia 2020). Diantara 10 wilayah perbatasan yang menjadi prioritas tersebut, Aruk merupakan salah satu daerah yang menjadi prioritas pembangunan naisional., alasannya di antaranya probelmatika pendidikan, ekonomi, aksesibilitas, keuangan daerah bahkan pada aspek sosial budaya, terutama pada tingkat eksistensi tatanan sosial masyarakat yang cukup rawan terhadap benturan-benturan budaya dari luar. Karena, daerah perbatasan merupakan wilayah strategis sebagai "wajah" suatu negara, menjadi pintu gerbang bagi warga atau pihak luar untuk masuk ke Indonesia.

Identifikasi batasan wilayah dari masyarakat perbatasan merupakan wilayah khusus yang sangat memerlukan perhatian khusus dibandingkan dengan daerah lainnya, terutama dalam hal problematika sosial budaya. Beberapa tahun terkahir dengan dibukanya jalur "Border" maka proses komunikasi antar budaya, suku dan ras ternyata memunculkan problematika sendiri. Fenomena ini terjadi dan menyebar di daerah-daerah kota dan kabupaten termasuk di antaranya adalah daerah perbatasan Kalimantan Barat khususnya kabupaten Sambas. Adanya komunikasi antar budaya yang dibawa oleh masyarakat berbeda agama, suku dan ras yaitu masyarakat pendatang yang muslim akhirnya menimbulkan pengaruh kepada eksistensi masyarakat lokal di perbatasan.

Sementara, kebudayaan masyarakat lokal yang sudah lama ada akan kesulitan tersendiri menghadapi budaya luar dalam menjaga eksistensi budayanya. Raisa Anakotta (2019), menyebutkan bahwa benturan dan resistensi dengan kebudayaan-kebudayaan luar pada akhirnya memaksa masyarakat lokal di perbatasan untuk tetap mempertahankan eksistensi budayanya yang selaras dengan jati diri kultural masyarakat lokal atau meleburkan diri pada budaya dari luar. Sebaliknya kemampuan masyarakat pendatang yang pada tataran ini beragama Islam untuk beradaptasi dengan mudah dan cepat dengan budaya "tempatan" (lokal), sehingga mudah masuk ke lapisan paling bawah dari kultur masyarakat lokal. Akibatnya, interaksi antar budaya yang terjadi dapat menyebabkan salah satu budaya hilang atau bahkan mengalami transformasi budaya. Oleh Sebab itu, dalam proses tersebut, masyarakat perbatasan akan memanfaatkan apa yang ada, membentuknya, bahkan mengubah beberapa hal yang dianggap paling sesuai dengan kebutuhan dan keinginan mereka yang kemudian dikenal dengan istilah bagian dari proses akulturasi budaya (Ambary 2001).

Realitas ini kemudian melatarbelakangi proses yang disebut dengan akulturasi melalui interaki sosial budaya antara budaya luar dengan budaya lokal. Roger dan Naylor mennegaskan bahwa akulturasi prinispnya merupkaan proses yang mendasar dari adanya proses adaptsi budaya dengan lingkungan (Nurhajarini, Purwaningsih, dan Fibiona 2015). Akulturasi secara konseptual, merupakan proses sosial yang muncul karena adanya interaksi antar kelompok manusia dengan suatu kebudayaan tertentu dengan unsur-unsur budaya lain dari suatu kebudayaan lain. Sehingga unsur-unsur budaya lain akan diterima dan direkonstruksi dalam kebudayaan sendiri tanpa menghilangkan jati dirinya (Ani, Abubakar, dan Iqbal 2019).

Berdasarkan asumsi dasar ini, terjadi akulturasi yang melahirkan sebuah 
kemampuan menyerap sambil menyaring atau menyeleksi dan mengelola kembali pengaruh budaya luar yang masuk, sehingga yang terjadi bisa saja menyebabkan salah satu budaya hilang atau bahkan mengalami transformasi budaya yang unik, yang berbeda dengan wilayah-wilayah lainnya. Sebagaimana disebutkan oleh Poespowardojo dalam Mustamir (2019) bahwa, secara implisit karakteristik local genius adalah mampu menjaga eksistensinya dari budaya luar, mampu megakomodasi unsur budaya dari luar, kemudian mampu kolaborasi unsur budaya luar dengan budaya masyarakat lokal, serta mampu mengontrol dan mengarahkan budaya luar menjadi trasnformasi budaya yang dipandang lebih baik. Maka dari itu, menjadi sangat menarik untuk dilakukan sebuah kajian mendalam, ketika proses akulturasi ini terjadi di daerah perbatasan yang notabenenya, sangat rawan akan resistensi kebudayannya.

Berdasarkan latar belakang tersebut, maka artikel ini akan membahas dan mendeskripsikan bagaimana proses akulturasi terhadap kondisi kehidupan sosial budaya pada masyarakat lokal dengan masyarakat muslim di perbatasan, khususnya masyarakat kecamatan Sajingan Besar kabupaten Sambas. Realitas sosial yang muncul akibat adanya proses komunikasi antar budaya ini, ada beberapa yang unsur budaya dan sub budaya yang mulai luntur. Memunculkan budaya baru, sehingga menjaga eksistensi kedua unsur budaya antara masyarakat budaya lokal dan pendatang (muslim) menjadi tantangan tersendiri di perbatasan. Oleh sebab itu, fenomena ini menjadi cukup menarik untuk dikaji secara komprehensif terkait proses komunikasi antar budaya khususnya proses akulturasi antara masyarakat lokal dengan masyarakat muslim di perbatasan. Adapun jenis penelitian ini ialah penelitian lapangan (Field Research), sesuai kategori dari penelitian kualitatif. Terkait dengan fokus penelitian, maka pendekatan yang dilakukan adalah melalui pendekatan studi Fenomenologi komunikasi masyarakat lokal dengan masyarakat pendatang yang beragama Islam di kecamatan Sajingan Besar secara subjektif. Asumsi dasar pendekatan fenomenologi merupakan studi tentang kemampuan untuk menafsirkan atau menjelaskan tindakan dan pemikiran manusia dengan cara mendeskripsikan secara komprehensif struktur dasar dari realita yang tampak (Denzin, Norman, dan Lincoln 2009).

Metode yang digunakan ialah dengan studi kasus yang berbasis instrumental. Cara kerja metode ini menggunakan paradigma naturalistik yang berusaha menguraikan persoalan penelitian kemudian menganalisis persoalan tersebut secara mendalam. Sebagaimana disebutkan oleh Norman K Denzin bahwa metode studi kasus ini merupakan bagian dari paradigma naturalistik dengan pendekatan fenomenologi (Denzin, Norman, dan Lincoln 2009). Adapun data primer dan sekunder diperoleh melalui tiga tahapan yaitu melalu observasi, wawancara dan studi dokumenter terhadap objek penelitian. Kemudian data yang diperoleh dianalisis berdasarakan teknik deskriptif analisis, tujuannya ialah untuk mendeskripsikan data dan hasil analisis yang lebih akurat, sesuai dengan fokus permasalahan.

\section{HASIL DAN PEMBAHASAN}

\section{Konstruksi Sosial dan Budaya Masyarakat Perbatasan}

Mengkaji tentang masyarakat merupakan bagian yang tidak terlepas dari aspek konstruksinya. Masyarakat dapat terwujud karena adanya aktivitas saling berpartisipasi antara elemen di dalamnya. Selain itu, masyarakat merupakan sekumpulan orang saling berkomunikasi melalui hubungan sebuah sistem sosial yang ada dalam lingkungan sekelompok orang tersebut. Dimana hubungan mereka ditopang oleh beberapa kesamaan diantaranya kesamaan budaya, wilayah, dan kesamaan identitas.

Kalimantan Barat merupakan daerah perbatasan yang memiliki posisi strategis. Ditinjau dari aspek geografisnya Kalimantan Barat merupakan wilayah Indonesia yang 
berbatasan langsung dengan negara tetangga, dan memiliki pintu masuk terbanyak dari beberapa daerah di Kalimantan. Menurut data administratif dari Lembaga Pengelola Dana Pendidikan, 5 Kabupaten di Kalimantan Barat merupakan pintu masuk dengan negara tetangga, diantaranya ialah Sambas, Sintang, Sanggau, Bengkayang dan Kapuas Hulu (https://dukcapil.kalbarprov.go.id/ 2020).

Berdasarkan kelima daerah perbatasan di atas, daerah yang memiliki heterogenisitas yang tinggi salah satunya ialah Sambas. Secara geografis Kabupaten Sambas merupakan daerah perbatasan terluar dan terdepan di Kalimantan Barat, kecamatan Sajingan Besar dan Paloh merupakan daerah terluar dan terdepan yang menjadi teras perbatasan di Kabupaten Sambas. Berbeda dengan kecamatan lainnya, kecamatan Sajingan Besar merupakan pintu masuk utama. Kondisi monografi masyarakat perbatasan, sebagaimana yang telah dijelaskan di atas merupakan daerah yang strategis. Daerah perbatasan di kecamatan Sajingan Besar tidak hanya sekedar persoalan letak geografis dan kondisi alamnya, tetap juga memiliki potensi dan kendala juga di berbagai bidang sosial lainnya. Potensi dan kendala tersebut seperti kependudukan, pendidikan, ekonomi sehingga pada sosial budayanya.

Beberapa aspek di atas, tentunya memiliki signifikansi dengan konstruksi sosial budaya yang kemudian memberikan dampak pada sistem dan komunikasi sosial budaya masyarakatnya. Sebutan untuk proses dimaksud itulah yang nantinya dikenal dengan istilah akulturasi. Koenjaraningrat menyebutkan bahwa ada elemen pembentuk yang mendukung terjadinya proses tersebut, yaitu kondisi masyarakatnya, individunya, saluran atau medianya, bagian masyaraknya yang terkena pengaruhnya, dan bagian masyarakat yang membawa pengaruhnya (Ani, Abubakar, dan Iqbal 2019).

Merujuk pada faktor utama konstruksi sosial budaya masyarakat tersebut, maka dapat dipaparkan beberapa data lapangan sebagai kondisi realitas sosial masyarakat di perbatasan. Data dari Badan Pusat Statistik kabupaten Sambas, kecamatan Sajingan Besar memiliki luas wilayah yang cukup luas jika dibandingkan dengan daerah Kecamatan lain di Kabupaten Sambas lainnya. Tetapi menempati urutan dengan kepadatan penduduk terkecil ketiga dari 19 Kecamatan di Kabupaten Sambas, yaitu hanya dihuni oleh 8 jiwa $/ \mathrm{km}^{2}$. Oleh karena itu, menjadi problematika sendiri bagi pemerintah daerah untuk mengelola pembangunan di daerah yang potensinya amat besar namun minimnya sumber daya manusia. Penduduk kecamatan Sajingan pada tahun 2017 berjumlah 11.197 jiwa. Jumlah Kepala Keluarga 2.547 (KK) atau Rumah Tangga. Adapun desa yang memiliki tingkat kependudukan tertinggi dari kelima Desa di Kecamtan Sajingan Besar adalah Desa Kaliau dengan Jumlah penduduk 2.685 jiwa, sedangkan Desa yang memiliki tingkat kependudukan terendah adalah Desa Sungai Bening jumlah penduduk 1.082 jiwa (Badan Pusat Statistik Kabupaten Sambas 2017).

Ada empat agama yang dianut oleh penduduk kecamatan Sajingan Besar. Penduduk yang bersgama Islam berjumlah 938 Jiwa, Katolik 7.985 Jiwa, Protestan 1.836 Jiwa, dan 9 Jiwa yang beragama Budha. Apabila dibandingkan dengan agama lain, muslim di kecamatan Sajingan Besar merupakan penduduk minoritas kedua setelah Budhis. Tingkat pendidikan penduduk kecamatan Sajingan masih tergolong rendah dengan mayoritas penduduknya hanya tamat sekolah dasar yaitu sebanyak 4565 jiwa, tidak tamat sekolah dasar sebanyak 1589, tamat SMP 1394, dan perguruan tinggi 78-72 orang (Badan Pusat Statistik Kabupaten Sambas 2017).

Aspek berikutnya yang juga memiliki kontribusi penting dalam memberikan pengaruh penting dalam kontruksi sosial masyarakat diperbatasan ialah kegiatan perekonomian. Beberapa hasil masyarakat menjadi andalan untuk menghidupi keluarga sehari-hari ialah berupa tanaman rempah berupa lada, daun sirih, buah pinang, serta buahan dan sayuran. Selain itu ada juga jenis tanaman produksi, seperti pohon karet dan pohon 
kayu alam juga sebagai penghasilan utama di masyarakat. Adapun jalur perekonomian masyarakat perbatasan dari hasil bumi tersebut diperjual belikan ke daerah kabupaten bahkan ke Malaysia.

Beberapa alasan mengapa masyarakat lebih memilih menjual ke Malaysia, menurut Ardinen penyebabnya adalah karena jaraknya yang tidak jauh, harga yang relatif lebih tinggi, kondisi jalan yang lebih baik dan cepat. Ditambah lagi dengan kondisi jalan setelah diresmikannya PLBN Aruk, cukup signifikan dengan aktivitas ekonomi masyarakat. Sehingga masyarakat lebih memilih berdagang atau membeli barang langsung di Negara tetangga. Realitas ini kemudian menyebabkan dialektika terjadi secara interaktif, proses komunikasi sosial antara dua negara, antara dua budaya (Interculutura).

Selain aspek-aspek di atas, aspek sosial dan budaya juga berperan penting dalam menetukan kontruksi sosial budaya di perbatasan Sajingan Besar. Untuk itu, apabila ditinjau dari aspek sosial budaya, masyarakat perbatasan di Sajingan Besar tergolong masyarakat heterogen. Secara umum masyarakat yang ada merupakan suku Dayak, Melayu, Jawa, Batak, Tionghoa. Untuk suku Dayak sendiri selaku mayarakat lokal dan juga sebagai mayoritas, dibagi menjadi 2 yaitu, ada ada suku Bekati' dan juga suku Badamea (Kandayan). Menurut kebiasaanya, setiap suku Dayak pada umumnya tidak berbeda dibanding dengan masyarakat pendatang lainnya, terutama dari tata cara bersosial, pola hidup, adat-istiadat sehari-hari. Tetapi yang mencolok membedakan dengan masyarakat pendatang ialah bahasa yang digunakan serta budaya lokal tertentu. Pada bahasa Dayak Badamea (Kandayan), misalnya, beberapa kata-kata hampir mendekati kata-kata dalam bahasa melayu atau Indonesia. Sedangkan suku Bekati sendiri sangat berbeda dengan suku dayak Badamea apalagi dengan suku selain Dayak. Sebagai contoh, kata "makan" dalam suku Dayak Kandayan menggunakan kata "Maka", sedngkan suku Bekati dengan mengucapkan " $U$ ".

Berikutnya, tidak hanya perihal aspek budaya sehari-hari yang berperan penting, tetapi ada juga norma atau nilai yang menjadi tolak ukur masyarakat dalam menjalin komunikasi di masyarakat yang berbeda budaya, yaitu adanya "Lembaga Adat". Sajingan Besar khususnya, peran lembaga adat ini ternyata cukup berperan besar dalam mengatur dan menjaga komunikasi masyarakat tetap kondusif.. Tidak hanya itu, lembaga adat juga menjadi penyelesaian permasalahan pertama jika terjadi keributan. Bahkan menurut Suprayitno yang merupakan anggota polisi Sektor Kecamatan Sajingan, posisi lembaga adat berada di depan pihak kepolisian. Kecuali permasalahan terjadi diluar kendali dan masalahmasalah vital.

\section{Akulturasi dan Komunikasi Sosial Budaya Masyarakat Lokal dan Muslim di Perbatasan}

Perbatasan di Sajingan besar merupakan garda terdepan negara yang menempati posisi paling strategis, karena menjadi jalur regional internasional antara Malaysia dengan Indonesia. Kondisi ini menyebabkan Sajingan Besar sangat rentan terhadap pengaruh budaya-budaya luar. Menjadi sebuah fenomena tersendiri ketika dibukanya jalur internasional Border Aruk, karena secara kontruksi sosial di lingkungan masyarakat akan terbentuk melalui dialetika sosial budaya antara masyarakat lokal dengan masyarakat muslim dari luar. Proses komunikasi inilah yang kemudian disebut sebagai sebuah proses akulturasi yang terjadi pada masyarakat perbatasan.

Akulturasi menurut para pakar budaya merupakan sebuah proses dialetika yang terjadi antar suatu kelompok manusia dengan kelompok lain, atau sering juga di pahami adanya komunikasi anta suatu budaya tertentu dengan unsur-unsur budaya lain (Nurhajarini, Purwaningsih, dan Fibiona 2015). Sehingga unsur-unsur budaya antara keduanya saling berdialektika, kemudian menjadi faktor penyebab hilangnya substansi suatu 
kebudayaan atau bahkan menimbulkan budaya baru di masyarakat. Sebagaimana menurut Redfield dalam Trinh (2009) menyebutkan bahwa akulturasi merupakan fenomena adanya saling berbaginya unsur kebudayaam berbeda antar kelompk atau idividu, sehingga terjadinya perubahan mendasar dari ciri keaslian budaya antara keduanya. Begitu juga dengan Santoso dan Winingsih sebagaimana yang dikutip oleh Anakotta (2019) menyebutkan bahwa akulturasi merupakan kontak dan perpaduan antara dua budaya atau lebih yang bersinergi untuk saling menjembatani karakter kedua budayanya. Semakna dengan Redfield yang dikutip Muzakkir (2019) menjelaskan bahwa akulturasi ialah fenomena sosial yang lahir karena adanya dialektika antar individu atau kelompok berbeda budaya yang mengakibatkan perubahan salah satu unsur budaya asal atau keduanya. Berdasarkan definisi ini dapat dimaknai secara substansi bahwa akulturasi menjadikan proses pengambilan atau pengiriman antar unsur budaya dari proses dialektika dua atau beberapa kebudayaan yang saling berkomunikasi. Dimana antara kedua saling mempengaruhi, dan juga bisa saling merubah antara keduanya.

Leininger dalam Ibrahim (2017) juga mendefinisikan akulturasi dengan istilah suatu proses belajar antara seorang atau sekelompok orang yang berbeda budaya, seperti belajar tentang nilai, norma, cara berpikir dan gaya hidup orang atau sekelompok orang lainnya. Seperti yang disebutkan oleh Ibrahim (2017), bahwa akulturasi merupakan proses suatu budaya seseorang yang dimodifikasi melalui proses interaski, baik itu melalui pemaparan secara langsung atau tidak dengan budaya luar melalui media massa. Demikian pula dengan Berry dalam Muzakkir (2019) memberikan keterangan lebih spesifik tentang cara atau strategi dalam kontek proses komunikasi antar dua budaya, yaitu adanya asimilasi, integrasi, separatis dan adanya marginalisai budaya yang di dukung oleh beberapa unsur usia, jenis kelamin, lingkungan, religion, serta dukungan sosial. Berdasarkan beberapa asumsi para pakar tersebut bisa difahami bahwa Akulturasi ialah bagian dari komunikasi sosial antara individu atau kelompok yang memiliki unsur budaya berbeda, sehingga menjadi faktor diterimanya unsur-unsur antar budaya tersebut ke dalam budaya salah satunya tanpa menyebabkan hilangnya ciri kekhasan budayanya, atau sebaliknya justru menghilangkan salah satu atau keduanya.

Akulturasi juga dapat dimaknai sebagai proses transformasi atau internalisasi budaya antar individu atau kelompok masyarakat. Koentjaraningrat (1990) dalam konteks ini menyebutkan bahwa akulturasi merupakan internalisasi budaya suatu masyarakat ke dalam budaya suatu masyarakat lain. Kemudian unsur budaya luar tersebut diakomodasi dan diintegrasikan ke dalam suatu budaya tanpa harus menghilangkan kekhasan budayanya. Koentjaraningrat menambahkan bahwa dalam proses akomodasi dan integrasi tersebut tidak semua unsur budaya bisa diakomodasi atau diinteegrasikan karena ada beberapa budaya yang memang mudah diserap, namun ada juga budaya yang sulit diserap oleh masyarakat. Merujuk pandangan tersebut, dapat disimpulkan bahwa, akulturasi ialah perpaduan antara dua unsur budaya berbeda dalam kehidupan sosial masyarakat yang bisa dipadukan antara kedua unsurnya. Namun ketika memiliki unsur yang sulit untuk dipadukan antara kedua kebudayaan tersebut maka akan membentuk budaya baru tanpa menghilangkan unsur kebudayaan asli atau bahkan menghilangkan budaya salah satu nya. Kerangka konseptual tentang akulturasi tersebut pada dasarnya relevan dengan realitas yang terjadi di daerah perbatasan Kabupaten Sambas. Seperti yang ada di masyarakat asli kecamatan Sajingan Besar dengan masyarakat luar yang transmigrasi ke daerah perbatasan dan masyarakat luar dari negara tetangga yaitu Malaysia.

Daerah perbatasan saat ini menjadi prioritas program pemerintah. Beberapa pembangunan telah dilakukan oleh pemerintah, mulai dari bidang ekonomi, perkebunan, infrastruktur dan sosial budaya dengan orientasi pengembngan daerah perbatasan. Pada 
satu sisi, pengembangan yang dilakukan oleh pemerintan dalam beberapa bidang tentunya memiliki efek dan pengaruh tersendiri dalam sistem sosial budaya masyarakat perbatasan. Terutama pengaruh sosial budaya masyarakat luar terhadap eksistensi sistem sosial budaya masyarakat lokal.

Beberapa pengaruh yang timbul, diantaranya dapat dilihat dari lima aspek, yaitu kependudukan, pendidikan, ekonomi, wisata dan aspek sosial budaya. Kelima aspek inilah kemudian yang memberikan kontribusi besar pada konstruksi sosial di perbatasan. Pada aspek kependudukan pertambahan jumlah penduduk di masyarakat perbatasan di Sajingan Besar memiliki dampak pada tatanan sosialnya. Dampak tersebut diantaranya semakin betambah juga jumlah keragaman budaya, keragaman suku, dan agama serta keragaman elemen-elemen masyarakat lainnya. Aspek pendidikan juga memberikan kontribusi bagi konstruksi sosial masyarakatnya. Terutama pola hidup masyarakat sudah mulai beralih dari yang tradisional menjadi lebih modern. Demikian pula dengan aspek perekonomian, pariwisata dan sosial budaya, melalui aspek-aspek ini, memungkinkan masyarakat untuk memiliki akses yang cukup luas untuk berkomunikasi dengan masyarakat luas, termasuk antara masyarakat lokal dengan masyarakat muslim diperbatasan.

Koentjaraningrat (1990) memberikan gambaran ketika suatu budaya dengan budaya lain saling berkomunikasi, maka sangat memungkinkan terjadinya akulturasi sosial budaya di masayarakat. Proses akulturasi ini dapat terjadi dalam dua bentuk, yaitu terdapat budaya lokal yang sulit dipengaruhi oleh unsur budaya dari luar atau desebut dengan covert culture. Kemudian ada juga disebut dengan overt culture yaitu budaya yang bisa di pengaruhi oleh unsur budaya luar. Covert culture tersebut meliputi aspek substansi dalam suatu budaya yaitu sistem nilai dan norma yang ada di masyarakat, keyakinan yang mengakar di masyarakat, adat istiadat yang turun temurun yang diinternasional dalam kehiudpan sosialisasi seharihari, dan beberapa pola hidup, cara berfikir dalam masyarakat yang dijadikan sebagai pengikat semua unsur sistem sosial masyarakat. Sebagai contoh sistem nilai yang melekat di masyarakat lokal yang diabstraksikan dalam bentuk aturan atau hukum sosial budaya masyarakat lokal setempat yaitu hukum adat, nilai, norma dan beberapa pola hidup yang telah dijelaskan sebelumnya.

Temuan penelitian menunjukkan bahwa hukum adat bagi masyarakat lokal merupakan eksistensi dari budaya turun temurun nenek moyangnya. Temuan ini dibuktikan dengan realitas bahwa ketika dalam proses penanganan pelanggaran kasus yang sifatnya konfilk horizontal maka dari pihak masyarakat akan menyelesaikannya dengan hukum adat terlebih dahulu. Namun, ketika kasusnya menyangkut kriminalitias dan kasus berat lainnya yang tidak selesai dengan hukum adat, maka proses hukum negara yang diberlakukan untuk menyelesaikan persoalan.

Temuan lainnya adalah ada budaya tertentu dari masyarakat lokal yang tidak bisa diganggu dari budaya masyarakat lokal, seperti budaya Naik Dangau. Sistem nilai ini, merupakan budaya lokal yang sangat kental nilai spiritualnya bagi masyarakat suku Dayak di perbatasan. Menurut keyakinan dan kepercayaan masyarakat lokal, prosesi ritual adat budaya mereka ini memiliki makna yang sakral, sehingga bagi siapa yang melanggarnya bisa dikenakan sanksi adat dari masayarakat lokal. Selain itu, budaya lainnya yang merupakan covert culture di masyarakat lokal perbatasan Sajingan Besar ialah budaya hukum adat bagi orang yang menabrak hewan ternak di jalan raya, baik itu Babi, Anjing, Ayam atau hewan ternak lainnya. Temuan penelitian ini menunjukkan bahwa sanksi hukum adat yang berlaku orang yang menabrak baik itu disengaja atau tidak, akan dikenakan sanksi berupa harus mengganti kerugian yang dialami oleh pemilik hewan. Adapun besarannya sangat bervariatif sesuai dengan kerugian yang dialami dari hewan tersebut. Realitas seperti ini oleh Koentjaraningrat (1990) disebut dengan covert culture, yaitu budaya bawaan yang sulit 
berubah ketika terjadi adanya dialetika budaya yang berbeda antara budaya lokal dengan budaya luar. Terbukti dengan dari kedua budaya di atas masih sangat kental dan mengikat bagi masyarakat lokal sehingga sangat sulit untuk dipengaruhi oleh budaya luar. Meskipun secara regional posisi masyarakat lokal sangat rentan terhadap pengaruh luar.

Komunikasi antar budaya memungkinkan terjadinya proses akulturasi di Sajingan Besar. Dalam konteks ini komunikasi dilakukan oleh masyarakat yang memiliki latar belakang budaya berbeda baik masyarakat lokal maupun pendatang yang berasal dari dalam dan luar negeri. Dalam kondisi ini budaya yang sulit berubah dengan sendirinya akan dipertahankan dan tetap eksis sebagai budaya bawaannya. Beberapa budaya yang masih tetap dipertahankan pada umumnya terkait dengan kepercayaan, bahasa, pola hidup bawaan antara keduanya baik itu masyarakat lokal maupun masyarakat muslim.

Bagi masyarakat lokal, kepercayaan terhadap berbagai hal yang sifatnya mistis masih diakui dan diyakini oleh sebagian besar masyarakat. Cara yang digunakan untuk menjaganya, biasanya meraka tanpilkan saat ada perayaan besar atau acara adat. Begitu juga dengan pola hidup masyarakat lokal, meskipun akses segala aspek sudah cukup memadai, namun pola hidup masyarakat lokal masih mengandalkan alam. Termasuk juga bahasa, yang digunakan oleh masyarakat lokal di mana kesehariannya masih menggunakan bahasa dengan dialek asli bahasa Dayak Bekathi' dan Dayak Badamea. Demikian pula dengan masyarakat muslim yang datang dari bebagai daerah. Kepercayaan yang dianut tetap dijaga dan dilestarikan meskipun berada di tengah-tengah komunitas Dayak dan non-muslim. Menariknya ditengah covert culture ini, beberapa seremonial keagamaan justru dilakukan dengan mengundang tetangga yang non-muslim, atau paling tidak berbagi makanan dengan tetangga yang masyarakat lokal. Begitu juga dengan pola hidup bagi masyarakat muslim, pada umumnya yang datang ke perbatasan ialah yang memiliki orientasi kerja, pedagang dan petani. Termasuk juga bahasa, masyarakat muslim ini cukup bervariasi karena tidak semua suku Melayu, tetapi juga suku Jawa, Sunda dan suku lainnya. Namun dalam berkomunikasi, bahasa Indonesia merupakan bahasa yang digunakan secara umum.

Sedangkan overt culture menurut Koentjaraningrat (1990) ialah kebudayaan fisik yang merupakan representasi dari sistem nilai yang ada di masyarakat. Bentuk overt culture diantaranya peralatan dan sarana yang menjadi bagian dari kehidupan keseharian masyarakat, rumah, tempat ibadah, alat bercocok tanam. Selanjutnya yang juga manjadi bagian dari overt culture ialah ilmu, ide, gagasan, pengetahuan, cara bercocok tanam, cara pikir, pola hidup, dan rekreasi yang berfungsi sebagai sarana untuk memudahkan dan memberikan kenyamanan bagi masyarakat. Bagian unsur budaya dan sub-budaya yang tersebut sifatnya mudah berubah, mengikuti perkembangan dan adaptasi sosial.

Overt Culture ini tidak hanya terjadi pada masyarakat lokal saja, namun keduanya memiliki tingkat resistensi yang sama. Overt cultre ini merepresentasikan adanya dialektika budaya. Ketika budaya asal atau bawaan yang sifatnya kebudayaan fisik ini, tidak disesuaikan maka dampaknya juga cukup besar. Sebagai contoh, cara pikir pola bercocok tanam jika masyarakat lokal dengan pola lama yaitu berpindah-pindah akan tidak relevan lagi dengan kondisi sekarang teknologi, tranfortasi dan informasi yang sudah cukup canggih. Contoh lain, pola hidup yang sifatnya kelompok-leompok atau komunitas tertentu saja, tertutup dari budaya luar tidak lagi relevan, karena jika ini dipertahankan maka akan sulit sekali masyarakat lokal untuk dapat berkomunikasi dalam aspek ekonomi dan sosial budaya.

Adaptasi budaya ini tidak hanya dialami oleh masyarakat lokal saja, namun sebaliknya juga dialami oleh masyarakat pendatang muslim khususnya. Ketika masyarakat pendatang berada dilingkungan masyarakat lokal dengan kebudayaan cukup mendominasi, maka mau tidak mau akan melakukan adaptasi budaya. Dalam konteks ini ada sebagian 
budaya dan unsur budaya bawaan juga harus dikomunikasikan dengan budaya lokal. Sebagai contohnya, ialah menyangkut aspek ritual ibadah yang menjadi bagian penting bagi masyaraat muslim diperbatasan. Dengan kondisi sebagai masyarakat minoritas, tentunya ada batasan dan ketentuan yang mesti disesuaikan, seperti lokasi tempat ibadah, akses yang mudah di jangkau oleh mayarakat umum bukan di perumahan masyarakat lokal. Serta ritual-ritual keagamaan yang mesti memperhatikan batas toleransi dan kewajaran untuk hidup berdampingan. Contoh lain, juga ialah ilmu pengetahuan masyarakat muslim juga harus berkembang dan memiliki pengetahuan yang luas tentang budaya masyarakat lokal atau sebaliknya. Melalui pengetahuan yag cukup terhadap unsur budayanya, keduanya akan mudah untuk saling mengenal dan memahami untuk dapat berkomunikasi dengan baik.

Merujuk pada asumsi dasar dari proses Overt Cultural tersebut, dialektika sosial budaya yang terjadi pada masyarakat perbatasan juga memiliki beberapa unsur budaya yang mulai berubah di masyarakat. Perubahan yang terjadi terbagi menjadi dua, yaitu perubahan yang sifatnya posisitif dan perubahan yang sifatnya negatif. Adapaun perubahan yang sifatnya positif, ialah seperti gaya hidup masyarakat yang dulunya sangat mengandalkan pendapatan pada sumber daya alam seperti menanam padi, menanam rempah-rempah, berburu dan tanaman lainnya. Semuanya sudah mulai ditinggalkan, masyarakat mulai beralih pada cara becocok tanam yang sifatnya praktis menggunakan alat mesin, berdagang dan pemanfaatan sumber daya alam sebagai objek wisata.

Adapun perubahan negatif ialah mulai lunturnya semangat nasionalisme masyarakat di perbatasan, dikarenakan mudahnya akses ke negara tetangga sehingga intensitas pergaulan akan lebih banyak dengan masyarakat luar. Akibatnya pengetahuan tentang kebangsaan dan nasionalisme sedikit demi sedikit mulai goyah, dengan berkurangnya rasa memiliki sebagai warga negara Indonesia. Sehingga, ketika ada budaya yang mudah berubah maka dengan sendirinya akan membaur dan menyatu bahkan sampai pada proses perubahan dari eksistensi budaya yang ada.

Realitas komunikasi dan akulturasi yang terjadi di daerah perbatasan khususnya di Sajingan Besar, dapat di gambarkan melalui pola berikut ini:

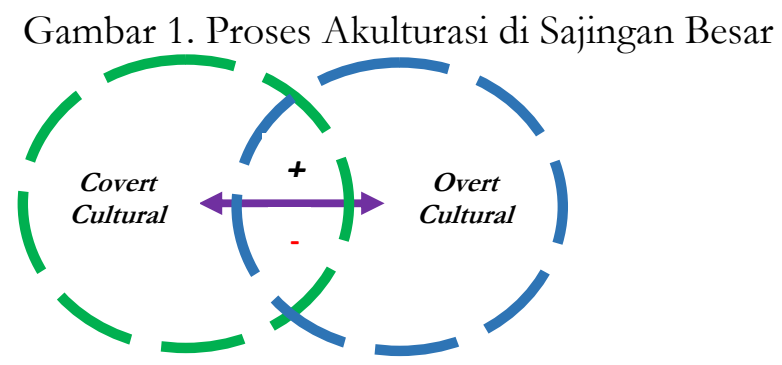

Deskripsi mendasar dari proses komunikasi budaya dan akulturasi antara masyarakat lokal dengan masyarakat pendatang yang terjadi di daerah perbatasan kecamatan Sajingan Besar dapat diuraikan dalam tiga dimensi. Pertama, unsur budaya dari budaya bawaan yang berbeda saling bercampur terjadi dialektika dan berkomunikasi dalam waktu yang relatif lama, tetapi keduanya mampu diletsarikan menjaga eksistensinya masingmasing. Seperti halnya hukum adat dan bahasa yang menjadi sub-cultural di Kecamatan Sajingan Besar. Kedua, terjadinya dialektika antar budaya berbeda, kemudian memunculkan budaya baru dengan tidak menghilangkan ciri kekhasannya. Pada aspek ini, kecenderungan perubahan yang terjadi sering mengarah pada hal yang posisitif, dimana masyarakat sangat dimudahkan dan diuntungkan dengan adanya budaya baru yang lebih praktis dan menunjang aspek sosial kehidupan masyarakat di perbatasan, Seperti halnya, budaya bercocok tanam, gaya hidup, dan ilmu pengetahuan. Ketiga, dengan adanya dialektika budaya dalam proses akulturasi antar budaya juga berdampak negatif, yaitu dengan mulai 
terkikisnya budaya lokal yang tidak bisa menjaga eksistensinya. Dampak ini misalnya budaya pengelolaan sumber daya alam dengan menjaga dan melestarikan hutan yang dianggap sebagai sumber penghidupan sudah mulai ditinggalkan, serta mulai ketergantungan dengan usaha perkebunan sawit. Demikian gambaran proses akulturasi yang terjadi di daerah perbatasan khususnya dialektika budaya antara masyarakat lokal dengan masyarakat muslim di perbatasan.

\section{PENUTUP}

Berdasarkan hasil paparan data dan analisis terhadap proses dialektika budaya antara masyarakat lokal dengan masyarakat muslim yang terjadi di Sajingan Besar, Sambas Kalimantan Barat ditarik beberapa simpulan. Pertama, akulturasi yang terjadi pada masyarakat perbatasan terjadi karena ada lima aspek yang mempengaruhinya, diantaranya aspek peningkatan jumlah penduduk, peningkatan tingkat pendidikan, mudah dan bebasnya akses perekonomian, objek wisata dan hetrogenitasnya sosial budaya di perbatasan. Adanya faktor tersebut, memberikan kontribusi besar terhadap rekonstruksi tatanan sosial masyarakat perbatasan. Adanya proses dialektika dan komunikasi antar budaya masyarakat lokal dengan muslim diperbatasan menjadikan terjadinya proses akulturasi antara keduanya atau sebaliknya. Berdasarkan hasil temuan lapangan paling tidak ada dua bentuk proses akulturasi, yaitu cover culutural dan overt cultural. Kedua, bentuk akulturasi ini mengakibatkan dua pengaruh besar bagi masyarakat setempat khususnya dan masyarakat pendatang umumnya baik negatif maupun positif. Pengaruh yang negatif meliputi mulai lunturnya budaya lokal yang mulai berkurang dan pola hidup tradisional yang mulai berganti lebih modern. Sedangkan pengaruh yang sifatnya positif meliputi, cara bercocok tatanam yang lebih praktis untuk menunjang kelangusngan hidup masyarakat setempat, cara berfikir yang lebih maju dan berkembang, dan gaya hidup yang lebih modern. Adapun berdasarkan proses akulturasi yang terjadi, melahirkan beberapa budaya, di antaranya, melahirkan budaya baru, seperti halnya budaya bercocok tanam, gaya hidup, dan llmu pengetahuan. Ada juga yang tetap menjaga eksistensi masing-masing substansi budaya seperti, bahasa, nilai dan norma bawaan yang melekat pada unsur budaya asalnya. Serta, menghilangkan budaya yang ada antara kedua budaya baik itu budaya masyarakat lokal maupun budaya masyarakat pendatang diantaranya cara hidup dari pola bercocok tanam yang tradisional ditinggalkan menjadi lebih modern. 


\section{DAFTAR PUSTAKA}

Ambary, Hasan Muarif. 2001. Menemukan Peradaban: Jejak Arkeologis dan Historis Islam Indonesia. Jakarta: Logos.

Anakotta, Raisa, Alman Alman, dan Solehun Solehun. 2019. "Akulutrasi Masyarakat Lokal Dan Pendatang Di Papua Barat.” Jurnal Antropologi: Isu-Isu Sosial Budaya 21 (1): 29_ 37. https://doi.org/10.25077/jantro.v21.n1.p29-37.2019.

Ani, Nor, Abubakar, dan Muhammad Iqbal. 2019. "Akulturasi Islam dalam Perkawinan Adat Dayak Ngaju: Sejarah Masyarakat Muslim di Desa Petak Bahandang, Kabupaten Katingan, Kalimantan Tengah.” Jurnal Studi Agama dan Masyarakat 15 (2): 107-17. https://doi.org/10.23971/jsam.v15i2.1624.

Badan Pusat Statistik Kabupaten Sambas. 2017. Monografi Data Kependudukan Kecamatan Sajingan Tabun 2017.

Denzin, K, Norman, dan Yvonna S Lincoln. 2009. Handbook of Qualitative Research. Yogyakarta: Pustaka Pelajar.

Hidayat, Ansori. 2018. "Dakwah Di Kalangan Masyarakat Transmigran: Studi Terhadap Kompetensi Da'i Di Dusun Cilodang Kecamatan Pelepat Kabupaten Bungo Jambi." NALAR: Jurnal Peradaban dan Pemikiran Islam 2 (2): 75-88. https://doi.org/10.23971/njppi.v2i2.963.

https://dukcapil.kalbarprov.go.id/. 2020. "Dinas Kependudukan dan Pencatatan Sipil Provinsi Kalimantan Barat.” 2020. https://dukcapil.kalbarprov.go.id.

Ibrahim. 2017. Komunikasi Antar Budaya. Pontianak: IAIN Press.

Khairani, Al-Donna Zhara. 2015. "Jargon - Jargon Politik Masa Orde Baru Dalam Menciptakan Stabilitas Nasional.” Avatara 3 (3). https://jurnalmahasiswa.unesa.ac.id/index.php/avatara/article/view/12326.

Koentjaraningrat. 1990. Sejarah Teori Antropologi II. Jakarta: UI Press.

Lubis, Arbiyah. 1993. Pemikiran Mubammadiyah dan Mubammad Abduh, Suatu studi Perbandingan. Jakarta: Bulan Bintang.

Maarif, Syamsul. 2017. Pasang Surut Rekognisi Agama Lelubur dalam Politik Agama di Indonesia. Yogyakarta: CRCS.

Mualimin. 2020. "Makan Besaprah: Pesan Dakwah Dalam Bingkai Tradisi Pada Masyarakat Melayu Sambas, Kalimantan Barat." Ath Thariq Jurnal Dakwah Dan Komunikasi 4 (1): 1-19. https://doi.org/10.32332/ath_thariq.v4i1.2017.

Mualimin, Ari Yunaldi, Sunandar, dan Alkadri. 2018. "Cultural Da'wah of Antar Pinang Pulang Memulangkan Tradition in Sambas Malay Society, West Kalimantan." Ilmu Dakwah: Academic Journal for Homiletic Studies 12 (2): 201-2013. https://doi.org/10.15575/idajhs.v12i2.1909.

Mustamir, Ahmad Khoirul. 2019. “Islam Nusantara: Strategi Perjuangan 'Keumatan' Nahdlatul Ulama." Jurnal Intelektual: Jurnal Pendidikan Dan Studi Keislaman 9 (3): 297310. https://doi.org/10.33367/ji.v9i3.1028.

Muzakkir, Muzakkir. 2019. "Konsep Akulturasi Budaya Masyarakat Tionghoa Ditinjau Dari Komunikasi Antar Budaya (Studi Kasus Etnis Tionghoa Di Wilayah Barat Selatan Aceh)." KAREBA: Jurnal Ilmu Komunikasi 8 (2): 258-74. https://doi.org/10.31947/kareba.v8i2.8872.

Nurhajarini, Dwi Ratna, Ernawati Purwaningsih, dan Indra Fibiona. 2015. Akulturasi lintas zaman di lasem: perspektif sejarah dan budaya (kurun niaga-sekarang). Yogyakarta: Balai Pelestarian Nilai Budaya (BPNB) Yogyakarta.

Sekretariat Kabinet Republik Indonesia. 2020. "BNPP Fokus Tangani 187 Kecamatan Perbatasan di 13 Provinsi." Sekretariat Kabinet Republik Indonesia. 2020. 
https://setkab.go.id/bnpp-fokus-tangani-187-kecamatan-perbatasan-di-13provinsi/.

Trinh. 2009. Handbook of Mental Health and Acculturation in Asian American Families. San Francisco: Springer Science. 